\title{
Functional Characterization of DNA Repair Proteins
}

D.M. Wilson

February 16, 2000 



\section{DISCLAIMER}

This document was prepared as an account of work sponsored by an agency of the United States Government. Neither the United States Government nor the University of California nor any of their employees, makes any warranty, express or implied, or assumes any legal liability or responsibility for the accuracy, completeness, or usefulness of any information, apparatus, product, or process disclosed, or represents that its use would not infringe privately owned rights. Reference herein to any specific commercial product, process, or service by trade name, trademark, manufacturer, or otherwise, does not necessarily constitute or imply its endorsement, recommendation, or favoring by the United States Government or the University of California. The views and opinions of authors expressed herein do not necessarily state or reflect those of the United States Government or the University of California, and shall not be used for advertising or product endorsement purposes.

This work was performed under the auspices of the U. S. Department of Energy by the University of California, Lawrence Livermore National Laboratory under Contract No. W-7405-Eng-48.

This report has been reproduced directly from the best available copy.

Available electronically at http://www.doe.gov/bridge

Available for a processing fee to U.S. Department of Energy

and its contractors in paper from

U.S. Department of Energy

Office of Scientific and Technical Information

P.O. Box 62

Oak Ridge, TN 37831-0062

Telephone: (865) 576-8401

Facsimile: (865) 576-5728

E-mail: reports@adonis.osti.gov

Available for the sale to the public from

U.S. Department of Commerce

National Technical Information Service

5285 Port Royal Road

Springfield, VA 22161

Telephone: (800) 553-6847

Facsimile: (703) 605-6900

E-mail: orders@ntis.fedworld.gov

Online ordering: http://www.ntis.gov/ordering.htm

OR

Lawrence Livermore National Laboratory

Technical Information Department's Digital Library

http://www.llnl.gov/tid/Library.html 


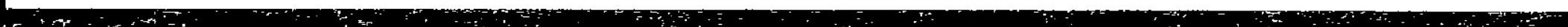

+ 
Functional Characterization of DNA Repair Proteins

PI: David M. Wilson III

Molecular \& Structural Biology Division

Biology \& Biotechnology Research Program, L-441

Lawrence Livermore National Laboratory

7000 East Avenue

Livermore, CA 94551

Purpose: Genetic material (DNA) is susceptible to spontaneous decomposition, to attack by reactive chemicals produced naturally in cells, and to assault by environmental and food mutagens. DNA modifications can lead to permanent genetic changes that promote human disease. To combat the deleterious effects of DNA damage, organisms are equipped with DNA repair systems. The focus of our investigations has been to elucidate the details of mammalian DNA repair. These studies have provided important insights into the relationship of DNA repair to human disease and the genetic factors that contribute to individual susceptibility to the harmful effects of environmental mutagens (e.g. ionizing radiation), and have established a framework for designing more effective anti-cancer treatment schemes.

Approach: To investigate questions related to DNA repair, its mechanism(s) and linkage to disease development, we are employing an array of molecular, cellular, biochemical and structural approaches. These complementary experimental techniques have permitted a detailed analysis into various processes of human DNA repair.

Technical Accomplishments: Sites of base loss (or AP sites) are frequently formed DNA lesions corrected by a multistep pathway initiated by an AP endonuclease. In mammals, the predominant AP endonuclease is Ape1. We have employed biochemical and structural approaches to elucidate the molecular detail of the Ape1-DNA complex. Computer modeling techniques have been used to elucidate which DNA elements influence Ape1 repair activity. Insights from these studies will now allow us to design inhibitor substrates that could prove useful in anti-cancer treatment schemes. We are also developing methods to isolate dominant-negative and increased repair capacity Apel proteins that may serve as radio-sensitizing or -protective agents when used with gene therapy approaches. In addition, we are working to generate mammalian cell lines deleted in $A P E 1$. The complementary nature of the biochemical and genetic projects will permit a thorough dissection of the biological contributions of Ape1. Finally, we have identified a second human protein with similarity to Ape1, termed Ape2, which will serve as a target for future investigations.

Free radicals are generated during normal oxygen metabolism or from exposure to ionizing radiation, and attack chromosomal DNA to form oxidative damage, including 3'-blocking termini. The repair of 3'-damages is not well understood. We are designing assays to identify repair factors involved in removing obstructive 3 '-ends and are presently testing several candidate 3' to 5' exonucleases. Developed in vitro assays may 
also serve as a means for assessing individual repair capacity and for predicting one's sensitivity to ionizing radiation.

The process most involved in preventing the harmful effects of spontaneous, oxidative and alkylation DNA damage is Base Excision Repair (BER). A reduction in BER would therefore lead to an increased risk of developing disease. We have identified variation among individuals in the human population in proteins of BER (Ape 1, Polymerase $\beta$, Xrccl and Ligase 3), and have shown that 6 of 9 variants in Ape 1 lead to reduced repair activity. We are now employing biochemical assays (e.g. DNA binding and proteinprotein interaction) to determine the impact of the observed variation on the integrated nature of BER. When combined with X-ray crystallography and computer molecular dynamics, these studies will determine which population-observed BER variation imparts reduced repair capacity, will elucidate the mechanistic basis for the reduced activities, and will establish a foundation for defining the relationship of genetic differences in BER to human disease susceptibility.

Nucleases are central contributors to DNA repair, recombination, and replication. Defects in these processes have been associated with increased cancer risk, neurological disorders, and premature aging. We have identified human $(\boldsymbol{H E X I / h E X O I )}$ and mouse ( $m E x o 1)$ genes that encode factors with homology to the RAD2 family of nucleases. Yeast genetic studies, mammalian expression analysis, DNA substrate specificity and protein-protein interactions suggest that the mammalian Exol proteins function in recombination and mismatch repair. Since we have only a fundamental understanding of the biological roles of the mammalian Exol proteins, we are expanding our biochemical studies and expression analysis, and have established a collaboration to generate a null mouse. These investigations will help determine the functional contribution of this important mammalian nuclease and its relationship to human disease. 


\section{Publications During 3 Years of LDRD Support}

Wilson III, D.M. and L.H. Thompson. Life without DNA repair. (1997) Proc. Natl. Acad. Sci. USA. 94:12754-12757. (UCRL-JC-128763)

Erzberger, J.P., D. Barsky, O.D. Scharer, M.E. Colvin, and D.M. Wilson III. (1998) Elements in abasic site recognition by the major human and Escherichia coli apurinic/apyrimidinic endonucleases. Nucleic Acids Res. 26:2771-2778. (UCRL-JC130481)

Wilson III, D. M., J.P. Carney, M.A. Coleman, A.W. Adamson, M. Christensen and J.E. Lamerdin. (1998) HEXl: a new human RAD2 nuclease family member with homology to yeast Exonuclease 1. Nucleic Acids Res. 26:3762-3768. (UCRL-JC-131255)

*cover featured article

Erzberger, J.P. and D.M. Wilson III. (1999) The role of $\mathrm{Mg}^{2+}$ and specific amino acid residues in the catalytic reaction of the major human abasic endonuclease: new insights from EDTA-resistant incision of acyclic abasic site analogs and site-directed mutagenesis. J. Mol. Biol. 290:447-457. (UCRL-JC-132629)

Lee, B.-I., M. Shannon, X. Chen, L. Stubbs and D.M. Wilson III. (1999) Expression specificity of the mouse exonuclease 1 (mExol) gene. Nucleic Acids Res. 27:4114-4120. (UCRL-JC-134081)

Lee, B.-I, and D.M. Wilson III. (1999) The RAD2 domain of human exonuclease 1 exhibits 5' to 3' exonuclease and flap structure-specific endonuclease activities. J. Biol. Chem. 274:37763-37769. (UCRL-JC-13567)

Hadi, M.Z., M.A. Coleman, K. Fildelis, H.W. Mohrenweiser and D.M. Wilson III. (1999) Reduced-function variants of the major human abasic endonuclease, Ape 1, identified in the human population. In preparation.

\section{Grant Support Stemming from LDRD Studies}

Department of the Army. PI. Repair Machinery for Radiation-Induced DNA Damage. Time Period: July 1, 1999 to June 30, 2002. Support: $\$ 388,000$ (total) for 3 years.

NIH R01. PI. DNA repair activities of human abasic endonuclease. Time Period: Apr. 1, 1998 to Mar. 31, 2002. Support: $\$ 1,226,751$ (total) for 4 years.

NIH R01. Co-PI with Dr. Michael Thelen. Function of the human XRCC1 protein in DNA repair and recombination. Time Period: Dec. 1, 1997 to Nov. 30, 2000. Support: $\$ 1,394,132$ for 4 years.

Co-investigator on five DOE projects within the Program. 